\title{
AT PLAY IN THE FIELDS OF THE WORD: COPYRIGHT AND THE CONSTRUCTION OF AUTHORSHIP IN THE POST-LITERATE MILLENNIUM
}

\author{
David LANGe*
}

In his celebrated essay, "What is an Author?," Michel Foucault suggested: "It would be pure romanticism . . . to imagine a culture in which the fictive would operate in an absolutely free state, in which fiction would be put at the disposal of everyone and would develop without passing through something like a necessary or constraining figure." 1

In this essay I offer just such an exercise in pure romance.

I consider some of the ways in which intellectual property doctrines, prompted into existence by the emergence of the printed word in the fifteenth century, have accommodated the ends of Western culture by enabling authority to authorize authorship in "fiction"-by which I mean, with Foucault (and, for that matter, Freud, Gadamer and Derrida, among others), creative play.

I observe how new technologies, the most significant among them still essentially beyond imagining as Foucault wrote, are undermining the efficacy of intellectual property as "a constraining figure" in the evolving embodiments of creative play.

I imagine a culture of precisely the sort Foucault thought "pure romanticism": a culture, that is to say, in which creative play is beyond the reach of constraint.

Indeed, I argue that such a culture is in fact at hand-that we see it now, and that we know it for exactly what it is: the marvelous, if fearful, proliferation of meaning (to paraphrase Foucault) awaiting us in the postliterate, post modern, post structuralist, antiformalist, surfictive millennium that lies ahead.

And finally I welcome the advent of such a culture, in which, at last, all are free to play in the fields of the word.

Copyright $\odot 1992$ by David Lange

* Professor of Law, Duke University.

1. Michel Foucault, What Is An Author? (Donald F. Bouchard \& Sherry Simon, trans), in Robert C. Davis \& Ronald Schleifer, Contemporary Literary Criticism: Literary and Cultural Studies 274 (Longman, 1989). 
Let me begin by recalling briefly what I think most students of intellectual property today accept as common ground: namely, the direct, and profoundly important, influence of the printing press upon the development of intellectual property doctrines. This is a matter of great historical interest in itself-and indeed it has had considerable development by intellectual property historians. ${ }^{2}$

When William Caxton brought the first press from Mainz to England in 1476, and installed it at Westminster at the Sign of the Red Pale, there is no reason to suppose that either he or his machine attracted much notice. The War of the Roses was still being fought on the plains of England; the attention of the Crown was fully engaged by this internecine strife. But in 1529, with the Tudor monarchy now more or less firmly on the Throne, and yet still in need of some means to suppress the steady stream of dissident speech that threatened the Establishment, Henry promulgated an Index Librorum Prohibitum, a formal edict against unlicensed manuscripts-an edict clearly meant to bring the press at last to heel. Other measures, including a formal system of licensing and censorship, followed almost immediately. ${ }^{3}$

Copyright grew directly from these efforts at suppression. To be sure, formal licensing ended in 1694 when Parliament finally allowed the Printing Act to expire. But the Stationers Company, to whom Phillip and Mary had issued a Royal Charter as early as 1557 , survived in the form of a guild. Lacking the protection of a license to print, however, and now confronting severe and unaccustomed competition in the form of what today we would no doubt call "pirate presses," the Stationers sought refuge in a petition to Parliament for an Act that would protect their "right of copy" in the books they themselves printed. Parliament responded, in 1709, with the first formal copyright act, the Statute of Anne. Anglo-American copyright, in all of its contemporary manifestations, can be traced directly to this Statute and to the history that led to its enactment. ${ }^{4}$

This much of the historic dependence of copyright upon the press is, as I say, common ground. But there is more still to be noted here. Not only did the introduction of the press into English life lead directly to the development of copyright in Anglo-American law-the press led also, in somewhat less

2. In a large field of excellent work, I would rank the writings of Ray Patterson as probably the most influential. Certainly no account of the historical development of copyight is complete without an acknowledgement of his thoughtful insights. See generally L. Ray Patterson, Copyright in Historical Perspective (Vanderbilt U Press, 1968). See also L. Ray Patterson \& Stanley W. Lindberg, The Nature of Copyright: A Law of Users' Rights (U Georgia Press, 1991).

3. At first modest, [these measures] grew more sweeping as the threat to established thought and order became more insistent. Letters patent evolved into a wide-scale system of printing monopolies, licenses, and privileges controlled by the Crown. By 1586, Elizabeth had expanded the scope of the Star Chamber Decree, so that only licensed stationers were permitted to print.

David Lange, The Speech and Press Clauses, 23 UCLA L Rev 77, 94-95, 94-95 nn 92-100 (1975). See generally the authorities cited therein.

4. See generally Patterson (cited in note 2). 
immediate but no less consequential ways, to our very ability even to think of creative expression as property. Indeed, were it not for the press, relentlessly propagating the linear text, intellectual property as we know it simply could not exist. What Saussure called "linearity" (or the "linear nature of the signifier") gives substance to "the concrete entities in language"; 5 and these "concrete entities" in turn become the subject of the "property" at the heart of the intellectual property system. In this sense, then, the press gave us not merely the occasion for the doctrines as well as the doctrines themselves, but also the very subject matter of the doctrines: that is to say, the res.

In law these observations are reflected in the so-called "idea-expression dichotomy," which is at the heart of all copyright theory, and which, more to the point, is the chief means by which copyright continues to fulfill its historic function as direct successor to the licensing mechanisms of the English Crown. In theory, copyright can appear quite benign: what is protected under the law is merely the expression; the idea within the expression always remains available to all; eventually, when the term of copyright has run, even the expression itself is injected into the public domain, where others may make of it whatever use they please. ${ }^{6}$ In practice, however, the copyright system proves troublesome, for at least three reasons.

First, of course, the copyright system does lend itself, infrequently but recurringly, to efforts aimed at the direct suppression of speech. Copyright theories figured, for example, in the United States Government's efforts to prevent the Pentagon Papers from being published; ${ }^{7}$ in Howard Hughes's attempts to suppress unwelcome biographies; ${ }^{8}$ and in Time, Incorporated's efforts to prevent the publication of photographs of the assassination of President Kennedy. ${ }^{9}$ In these cases the efforts at suppression ultimately proved unsuccessful-though, significantly, they could not be dismissed out of hand. Other efforts, meanwhile, have succeeded: in the suit by Gerald Ford and his publisher against Nation magazine, for example, which had the effect of limiting and delaying the publication of Presidential memoirs; ${ }^{10}$ in $\mathrm{J}$. D. Salinger's suit against a biographer who was prevented from publishing letters actually already on deposit in a library; ${ }^{11}$ and (in some ways more significant than either of these cases) in numerous suits by the proprietors of expression one might call "valuably bourgeois"-of which the first example that comes to mind is Walt Disney's action to suppress the satiric distortion of

5. See Ferdinand de Saussure, "Nature of the Linguistic Sign" and "The Concrete Entities of Language," from Course in General Linguistics (The Philosophical Library, 1959), in Davis \& Schleifer, Contemporary Literary Criticism at $159-65$ (cited in note 1).

6. I presuppose the general familiarity of the reader with copyright and related intellectual property doctrines throughout this essay. For readers who need or wish general references, the leading treatises in the field are Melville B. Nimmer \& David Nimmer, Nimmer on Copyright (Matthew Bender, 1991) and Paul Goldstein, Copyright: Principles, Law and Practice (Little Brown, 1989).

7. New York Times Co. $v$ United States, 403 US 713, $726 \mathrm{n}^{*}$ (1971).

8. Rosemont Enterprises, Inc. v Random House, Inc, 366 F2d 303, 306-07 (2d Cir 1966).

9. Time, Inc. $v$ Bernard Geis Associates, 293 F Supp 130, 141-44 (SDNY 1968).

10. Harper E Row, Inc. v Nation Enterprises, 471 US 539, 569 (1985).

11. Salinger $v$. Random House, Inc., 811 F2d 90, 99-100 (2d Cir 1987). 
Mickey Mouse at the hands of the counterculture in "head comics," circa 1969-78. ${ }^{12}$ Of course, these cases have led to a small but substantial body of professional literature, the burden of which has been to establish that what is taking place is not taking place, or is taking place acceptably despite the apparent conflict with the first amendment; but what this literature actually succeeds in establishing, I think, is that Stanley Fish is correct: first we do what comes naturally, and then we invent some "theory talk" to make our efforts plausible. ${ }^{13}$ And what comes naturally to copyright-what has always been there, embedded in the history of copyright, and what remains when all is said and done-is the deliberate, if selective, suppression and advancement of speech.

Second, copyright is a major "player" in the establishment of institutions that, at a secondary level of engagement, also serve to validate some speech at the expense of other speech. I have in mind, of course, the institutional Press or Fourth Estate, which could not exist comfortably in its present form without some protection against copying. But the Press is small change compared to the rest of the media, including the entertainment industry, which are absolutely dependent upon intellectual property for the revenues that give the media their present character. And of course we prize that character for many reasons. Indeed, entertainment appears to be the last great field of productivity within which the United States enjoys undisputed hegemony throughout the world. In this connection, then, and others, intellectual property directly advances the economic and cultural interests of not merely the media, but the Nation at large.

Third, I would say that copyright is capricious. Sometimes, to be sure, it leads the creative individual to recognition and reward. Too often, thoughor so I think-it threatens embarrassment and ruin. In this sense copyright seems to represent an assault upon creative expression or play, carried out in two rather specific ways. On the one hand, copyright imperils the essence of the creative process by penalizing the unconscious infringement. I suppose almost everyone knows how George Harrison's "My Sweet Lord" was found to be an infringement of the earlier "He's So Fine," despite the court's conviction that Harrison actually had no recollection of the earlier song when he composed his own. ${ }^{14}$ This is an outcome defensible, if at all, only if one sees the issues essentially in economic terms. The impact on creativity is altogether indefensible-at least I have never encountered a persuasive defense of it; and yet it is a mainstay of copyright jurisprudence that innocence is not a defense to a finding of infringement. Meanwhile, always, copyright inhibits (when, indeed, it does not suppress outright) the creation of what copyright lawyers call "derivative works": those works in which the invention lies in deliberate imitation and improvement-works which,

12. Walt Disney Productions v Air Pirates, 581 F2d 751, 756-80 (9th Cir 1978).

13. Stanley Fish, Dennis Martinez and the Uses of Theory, in Doing What Comes Naturally: Change, Rhetoric, and the Practice of Theory in Literary and Legal Studies 373-98 (Duke U Press, 1989).

14. ABKCO Music, Inc. v Harrisongs Music, Ltd., 722 F2d 988, 998-99 (2d Cir 1983). 
historically, have been among the most sublimely creative human achievements. ${ }^{15}$

These surely are troublesome aspects of the relationship between copyright and society. In each instance, copyright proves to be (or to have the capacity to be) suppressive. In each case the mechanism of suppression lies embedded in the concept of authorship. And here, surely, is a curious circumstance. We value authorship, or so we say insistently in the main theories of the field. And yet it appears, again and again, that we merely value some authors, and then at the expense of others. Eventually, it would seem, we must ask what it is, exactly, that we prize in authors. ${ }^{16}$

Why do we "attach a certain importance" to authorship? Foucault tells us:

The author allows a limitation of the cancerous and dangerous proliferation of significations within a world where one is thrifty not only with one's resources and riches, but also with one's discourses and their significations. The author is the principle of thrift in the proliferation of meaning. As a result, we must entirely reverse the traditional idea of the author. We are accustomed . . to saying that the author is the genial creator of a work in which he deposits, with infinite wealth and generosity, an inexhaustible world of significations. We are used to thinking that the author is so different from all other men, and so transcendent with regard to all languages that, as soon as he speaks, meaning begins to proliferate, to proliferate indefinitely.

The truth is quite the contrary: the author is not an indefinite source of significations which fill a work; the author does not precede the work; he is a certain functional principle by which, in our culture, one limits, excludes, and chooses; in short, by which one impedes the free circulation, the free manipulation, the free composition, decomposition, and recomposition of fiction. In fact, if we are accustomed to presenting the author as a genius, as a perpetual surging of invention, it is because, in reality, we make him function in exactly the opposite fashion. One can say that the author is an ideological product, since we represent him as the opposite of his historically real function .... The author is therefore the ideological figure by which one marks the manner in which we fear the proliferation of meaning. ${ }^{17}$

Rich in insight though this passage is, I think it still does not quite capture the subject. Foucault, himself a Marxist, says that "since the eighteenth century, the author has played the role of the regulator of the fictive, a role quite characteristic of our era of industrial and bourgeois society, of individualism and private property ...."18 And of course I think this is partly true. But his statement does not recognize-at least it does not acknowledge-the larger role of authorship in at least the three previous centuries as well-centuries in which, not bourgeois society, but rather the authority of the Crown, was implicated.

It is essential to intellectual property and authorship as we know them that there have been a press and a state. In contrast, it is a mere parochial datum that authorship has served the purposes of the bourgeois society in which we

15. See Peter Jaszi, When Works Collide: Derivative Motion Pictures, Underlying Rights, and the Public Interest, 28 UCLA L Rev 715, 729-32 (1981).

16. Compare Peter Jaszi, Toward a Theory of Copyright: The Metamorphoses of "Authorship," 1991 Duke L J 455.

17. Foucault, What is an author? at 274 (cited in note 1).

18. Id at 274-75. 
happen now to live-though in fact, no doubt, it has. Plagiarism, attribution, distortion, truncation, mutilation, and the like-the so-called "moral rights"19_are an obsession of the bourgeoisie. The fact remains that authorizing speech, historically, has been the work of the state-of any state, whether bourgeois or not. And it is for reasons implicit in that larger history that intellectual property and authorship cannot easily be defended in any society today which prizes freedom of expression.

\section{II}

Meanwhile, however, it has become an interesting question whether authorship under the regime of intellectual property can continue to exist against the contemporary background of evolving technologies-or in a world of increasingly radical personal singularity.

In this connection I shall draw upon the recent work of another scholar, and draw upon it at some length, not only because that work offers an account precisely suited to my own eventual ends, but also because it leads to just the question I myself wish to ask: If the press has given us the intellectual property system we have, then what can we expect of an age in which the press no longer will be the chief source of the ways in which we think and communicate with each other-and even more to the point, an age in which, thanks to the proliferation of alternative and advancing technologies, we will increasingly encounter what Frederic Jameson calls "the signatures of the visible"?20

Here, then, is Tom Palmer, of the Institute for Humane Studies at George Mason University, writing on the "historical interdependence" of technology and intellectual property:

One need not be a historical materialist or economic determinist to realize that not only the economic circumstances that might prompt movement toward recognition of "new" property rights, but also the very concepts by which these rights would be structured are contingent upon technology.

The concept of personal and individual authorship, as we understand it today, was dependent upon the "invention" of the typographically fixed title page. Typographical fixity was also necessary to fix the identity of the text itself. Before the introduction of printing, works were copied and recopied, often introducing a multiplicity of minor errors, additions, or deletions by scribes. The proliferation of works attributed to classical authors (many now often cited with the prefix "Pseudo" before the name under which the work appeared) was a natural outcome of scribal culture.

As Elizabeth Eisenstein has demonstrated, "[s]cribal culture could not sustain the patenting of inventions or the copyrighting of literary compositions. It worked against the concept of intellectual property rights." With the typographical fixity and attribution made possible by printing, authorship became a matter of personal responsibility, and respect for the "wisdom of the ages" correspondingly declined. Authorship and invention, the very acts to be rewarded by intellectual property law, may not be timeless concepts plucked from Heaven but may emerge in conjunction with-and be inextricably intertwined with-the technology that makes them possible.

19. See generally Goldstein, Copyright at $\$ \S 15.23$ et seq (cited in note 6).

20. Fredric Jameson, Signatures of the Visible (Routledge, Chapman \& Hall, 1990). 
The relationship between intellectual property rights and technology poses a very important question: If laws are dependent for their emergence and validation upon technological innovations, might not succeeding innovations require that those very laws pass back out of existence? ${ }^{21}$

The answer is, of course they might. And I think Palmer has every reason to ask this question, given the degree to which new technologies are undermining the efficacy of intellectual property in our time.

I am not much inclined, by age, temperament or training, to be enthusiastic about new technology; but neither am I blind to what is happening in our time. Indeed, no sentient being can fail to see how radically, and rapidly, our world is being altered. My colleague Pam Samuelson, who is an authority on technology, recently sent me a brief description, for example, of the "Rokeby Synthesizer," which surely is among the most conceptually intriguing technologies to appear recently, and which raises questions she herself addresses in a paper she gave at a symposium in Japan:

My favorite [among a number of new systems made possible by advance computer program technologies] was one that generated synthesized music in response to movements of a person (or other form) located at the vortex of two video cameras which were mounted at opposite corners of the ceiling of the room. The cameras were connected to a computer which transformed the digital video signals related to the movement of a person into an auditory form. (That is, no sound was generated when no one was in the room, or when a person in the room was still. Sounds were only generated in response to movement.) By changing the pace at which one moved and the amount of movement, one could change the sounds generated. If one wanted to created the sound of chaos, jumping up and down with all limbs flailing wouid do the trick. By contrast, small movements of one's little finger would make a sound like a high-pitched flute ....

David Rokeby, who developed this system, considers himself a performance artist, and he surely is. But how profoundly technological is his medium of expression. There are a great many intellectual property law questions his system raises, among them: Who is the "author" of the music his system generates? Is his system patentable, copyrightable, both or neither? What aspects of his creation can these laws encompass? What aspects do these laws fail to grasp? ${ }^{22}$

These questions are inevitable when technology as remarkable as this appears on the horizon. And I think Pam Samuelson poses them here exactly as they are being asked around the world.

But the question I want to pursue in this essay is somewhat collateral. The fact is that new technologies have confronted intellectual property, repeatedly, for at least a century without provoking more than essentially cosmetic responses. Is there reason to suppose that our experience will be different now? In fact I think there is.

One might have supposed that the end of copyright was at hand when photography entered the field in the nineteenth century. For the challenge to

21. Tom G. Palmer, Intellectual Property: A Non-Posnerian Law and Economics Approach, 12 Hamline L Rev 261, 271-73 (1989).

22. Pamela Samuelson, Summary of Remarks, Some Challenges New Information Technologies Pose For Existing Intellectual Property Law Systems, SOFTIC Symposium '91-Third International Symposium on Legal Protection of Computer Programs, Panel Session 2, Tokyo, Japan, February 20, 1991. 
copyright offered by photography lay in the fact that the idea-expression dichotomy - which, as we have seen, was central to the concept of "property" in the linear text generated by the press-no longer made sense when the medium was one in which idea and expression could be perfectly merged-in which, indeed, idea and expression were meant to be merged. ${ }^{23}$ And yet, as it happened, nothing happened. Copyright went right on trying to protect expression without appropriating ideas-which is to say, that copyright simply began to work even more imperfectly than before.

Why should this have been so? No doubt there were many reasons, but I would say that foremost among them was the fact that the technology in private hands did not come into important contact with any of the more insistent commercial uses to which that technology might be devoted under the copyright regime. As a result, public acceptance of the body of positive law-a law the public actually might have had some reason to resist in circumstances involving closer contact-could go on being taken more or less for granted.

All of that began to change, irreversibly, with the advent of easy copying about twenty-five years ago. First the xerox, then the audio cassette, then the VCR, and then-well, but you can see the point. Not challenges to the conceptual structure of copyright, but rather to the moral claim it makes upon us, are why one can say with a sense of assurance that today's technologies are destined to change the way we think about property in creative play, forever.

I say "the moral claim," but even that is not exactly what I mean. What I really have in mind is our innate emotional hunger for creative play, and our considerable incapacity to resist indulging it. The child playing in the sand on the beach builds castles, which no one but a monster would imagine forbidding a second child to imitate at will. Creative play in childhood becomes the adult fantasy that we recognize in authorship, and it is no less monstrous to limit authorship among adults than it is among children. Nor, for that matter, is it possible, except in circumstances amounting to physical exclusion. We have succeeded in limiting authorship only through our success in controlling access to its chief tangible mediums of embodiment. And now we have lost our ability to limit that access. Resistance to the claims made against our interests by intellectual property will follow increasingly, exactly as resistance already has begun to manifest itself in the past quarter century. ${ }^{24}$

23. See Jane M. Gaines, Photography 'Surprises' the Law: The Portrait of Oscar Wilde in Contested Culture: The Image, the Voice, and the Law 42-33 (UNC Press, 1991).

24. I claim no originality in what I have said in this essay about technology and intellectual property developments in the past quarter century; indeed, I intend my observations here to seem familiar to anyone who has any grounding in the field. For a useful collection of citations to relevant literature, see Jessica Litman, Copyright Legislation and Technological Change, 68 Oregon L Rev 275, 277 (1989).

My observations about play and fantasy are derived directly from Freud, in whose works they appear recurringly. See, for example, Creative Writers and Day-Dreaming, in Sigmund Freud, Standard Edition of Collected Works, volume ix, at 143-53 (The Hogarth Press, 24 vols 1906-08). 
Inevitably, of course, there is resistance within resistance. More so today than at any time in this century, the fundamental jurisprudence of copyright is undergoing critical examination. Basic questions are being raised: Is copyright justified? Or is it an encroachment upon the public domain? Are there alternatives, adequate to the purpose of whatever economic justification there may be in the law, yet less intrusive into the realm of creative play? And so on. ${ }^{25}$

These are important issues. They deserve the attention they are getting. And I share the interest of others in the field in seeing them intelligently resolved in the near term.

For myself, however, I must say I sympathize with much of the balance of Tom Palmer's monograph, in which he offers an Austrian economic analysis of intellectual property notably and explicitly at odds with the more conventional analysis of lawyer-economist Benthamites like Richard Posner. When Palmer concludes, as he does, that "patents and copyrights have no place in a regime based on individual rights ....," I think his conclusions are justified to a very considerable degree. ${ }^{26}$

And I think so despite the powerful arguments of intellectual property defenders-among them, one of the field's most valuable scholars, Wendy Gordon-who accept, as Palmer does not, the intuitive appeal in John Locke's justification for property-that is, his justification for recognizing as one's own those "things" that are conjoined with one's labor, always supposing that what remains for others is "sufficient" and "as good."27 Against the position of these scholars I would argue that what remains for others when intellectual property has been created never is "as good," and cannot ever be "sufficient." As Judge Seabury once observed, we must remember, when we consider rights in authorship, that we are not merely dealing in so many barrels of pork. What is at stake here is the interdependence of texts, and it is as meaningless to speak of "as good" and "sufficient" in this context as it was to speak of "separate but equal" before Brown v. Board of Education.

But for my purposes in this essay, finally, what matters more is the prospect (if not inevitability) I think no student of the field of copyright can afford to ignore: whatever theoretical justification there may have been for copyright under the regime of the press and the linear text, in the post-literate millennium that lies ahead, given the technologies that are already at hand, we will surely encounter the end of authorship as we have known it, and the emergence of a new experience of creative play.

25. See, for example, Wendy H. Gordon, An Inquiry Into The Merits of Copyright: The Challenges of Consistency, Consent, and Encouragement Theory, 41 Stan L Rev 1343 (1989). Despite my disagreement with some of the author's conclusions, I think this is an exceptionally fine piece of work.

26. Palmer, 12 Hamline $\mathrm{L}$ Rev at 304 (cited in note 21). The "Benthamite" reference is Palmer's, not mine.

27. Gordon, 41 Stan L Rev at 1446, $1446 \mathrm{n445}$ (cited in note 25). 


\section{III}

But what constraints upon creative play will we yet encounter in the postliterate millennium?

In Foucault's vision, fiction will always be subject to "something like a necessary or constraining figure," though authorship itself may vanish:

[G]iven the historical modifications that are taking place [in society], it does not seem necessary that the author function remain constant in form, complexity, and even in existence. I think that, as our society changes, at the very moment when it is in the process of changing, the author function will disappear, and in such a manner that fiction and its polysemous texts will once again function according to another mode, but still with a system of constraint-one which will no longer be the author, but which will have to be determined or, perhaps, experienced.

All discourses, whatever their status, form, value, and whatever the treatment to which they will be subjected, would then develop in the anonymity of a murmur. We would no longer hear the questions that have been rehashed for so long: Who really spoke? Is it really he and not someone else? With what authenticity or originality? And what part of his deepest self did he express in his discourse? Instead there would be other questions, like these: What are the modes of existence of this discourse? Where has it been used, how can it circulate, and who can appropriate it for himself? What are the places in it where there is room for possible subjects? Who can assume these various subject functions? And behind all these questions, we would hear hardly anything but the stirring of an indifference: What difference does it make who is speaking? ${ }^{28}$

This is all quite elegantly put, of course, but I think Foucault has it exactly backward. I think it is authorship that will survive, though in radically personal form, and the constraining figure of societal (or state) authority that will vanish-and with it, in all likelihood, intellectual property as we know it.

Foucault's error lies in imagining that authorship has to be what we've made of it. Authorship as an artifact of authority is indefensible; it deserves to die. But authorship in the preliminary sense of identifying, merely entre nous, the "person to whom something owes its origin" is not only defensible, but inevitable as well. Indeed, I would venture to say it has been an essential requirement of human existence from our earliest beginnings.

Authorship in this original sense situates us in our relationship with others, and is therefore the means by which we gauge our place in the world; it is a necessary antecedent to understanding. We may sense others in ourselves; but we know ourselves through our gifts to others and theirs to us, and we come to that understanding most naturally through gifts of selfexpression-through the creative fantasies, that is to say, that Freud identified as the adult equivalent of childish play. It is this capacity to give a part of one's self that creative play allows us to develop. And it is through creative play, given and received and given back again, that we define the individual reality in our lives.

Gifts exchanged "in the anonymity of a murmur" will not do.

I would say that this is why, in our time, just as the form of authorship Foucault identified is being swept away, the form of authorship I am identifying is so remarkably omnipresent in the very fields in which creative

28. Foucault, What is an Author? at $\mathbf{2 7 5}$ (cited in note 1). 
play has been imprisoned for so long. This is an authorship probably unintended, to be sure; and yet it is an authorship insistently implicit in much of contemporary literary criticism-an authorship of interpretation, of creator-with-reader, of playmates at large. Indeed, in the work of Jacques Derrida, Hans-Georg Gadamer, or Jurgen Habermas, for example, play itself is a recurring motif.

Consider Jay Mootz' account (in a recent essay on legal hermeneutics) of Gadamer's explicit reliance on "play" in Truth and Method:

Gadamer uses the concept of Spiel, or "play," to express the mode-of-being of the work of art, and he investigates this ontological dimension of all aesthetic experience as a manifestation of the mode of being-in-the-world that he explores with his general hermeneutical theory. The proposition that an individual is "at play" with a work of art is not as innocuous as it may appear, for it takes issue with the Western philosophical tradition and its central belief in the subject/object dichotomy. Gadamer contends that a work of art is not something that a viewer makes sense of by organizing his subjective feelings or by ingeniously decoding the meaning created by the artist. Nor does the work of art stand as a distinct object that admits of empirical verification and logical consistency. To be at play with a work of art is to relinquish the pretense of subjectivity and to follow the possibilities offered by the work, without losing one's individuality or perspective (an impossibility!) or wholly subordinating the meaning of the artifact to one's creative powers. The work of art has an autonomous existence apart from the viewer's subjective aims, and like two dancers who are given over to the dance, the artwork and the individual each make claims of meaning upon the other.

Gadamer's point is conveyed more readily through an example. The game of "patty cake" takes both players beyond their individual intentions: neither person is able to assert herself as the "player" and make the other a mere "playee." There is a degree to which each player is outside herself in the communion of playing with another, and the coordination of their clapping is akin to a dance. It is neither trite nor imprecise to say that our ability to play patty cake is the sine qua non of our ability to appreciate and understand art, for it is this mode of being-our givenness to play-that characterizes the aesthetic experience. It is important to recognize, however that "the mode of being of play is not such that there must be a subject who takes up a playing attitude in order that the game may be played." An individual neither induces nor creates play; rather it occurs "not only without goal or purpose but also without effort. It happens, as it were, by itself." In short, human beings are ontologically playful.

Yet this playfulness is not unsituated. It takes place within the parameters of a structure that the participants establish; there are "rules" to the game that constitute a setting or context for play. Art is play that has been transformed into a particular structure-a painting, sculpture, or symphony-that engages the spectator with each viewing or presentation. ${ }^{29}$

But if this is what it means to be "at play" with a work, then is there room for liberated authorship, even of the sort I have envisioned? Are constraints inherent in the rules of the game? And is the question, then, as Foucault imagined after all: not, who is speaking? but rather, what is the mode of this discourse?

Again, I would insist that the requirements of human existence will not suffer the author to die. What does it matter who is speaking? The answer

29. Francis J. Mootz, The Ontological Basis of Legal Hermeneutics: A Proposed Model of Inquiry Based on the Work of Gadamer, Habermas and Ricoeur, 68 BU L Rev 523, $531-33$ (1988). 
is-when it is we who are speaking with those with whom we speakeverything.

Meanwhile, the technology of our age insures that living authors eventually will be free, even from the incidental constraints implicit in Gadamer's rules of the game. Gadamer's game presupposes a language verbal (or linear) in nature. As Jay Mootz explains: "Gadamer argues that all human experience is ontologically structured through language (both verbal and potentially verbal). Language is not a tool for consciousness to exploit but is a lived-through reality that structures our playful existence."30 But Gadamer, like Foucault, reckons without accounting for the impact of contemporary technology: already, verbal language is passing, if not from existence, then at least from its accustomed place of primary importance in human experience. In this sense, eventually, we will all confront a fearful proliferation of meaning, exactly as Foucault supposed.

What will our world be like? How will we live with each other as our verbal language yields to the "signatures of the visual"? The answer lies, I think, in the telling final scene from Diva, the remarkable film by Jean-Jacques Beneix-a film Fredric Jameson calls "postmodern" and analyzes as though it had something (anything!) to do with French Socialism, ${ }^{31}$ but which in fact has nothing really to do with anything linear at all, and is therefore fairly to be called "post-literate," "post-structuralist," "antiformalist," and "surfictive."

In Diva, the artist, Cynthia Hawkins, an American soprano-whose marvelous voice unfortunately has begun to give some slight evidence of premature unreliability-attracts the attention of Jules, a messenger boy who cruises the streets of Paris on a Moped to make his deliveries. Jules is bewitched by the Diva-not merely by her beauty, but by her music; he attends a recital at the Opera where he secretly tape-records her as she sings an aria from "La Wally." After the performance, while no one is looking, he chances upon an opportunity to steal the gown she wore on stage-and, impulsively, he does so. Paris is scandalized. But Jules, alone at night in the romantic loft he occupies above a warehouse in a fashionably seedy arondissement somewhere on the Left Bank, listens to the tape, fondles the gown, and is transported.

In time, through plot devices I need not account for here, Jules meets the Diva; she befriends him; eventually they spend the night together, though in circumstances implying chastity. Other things happen as well: The illicit tape Jules made attracts the attention of gangsters who misunderstand its meaning. Fearful, they pursue him. But he escapes, thanks to a timely proliferation of tapes having other, still more fearful, meanings. Meanwhile, the Diva, pressed by her manager to permit an authorized recording of her work while she still is able, refuses: no recording, she insists, could ever capture the essence of the relationship between an artist and her audience in the course of a

30. Id.

31. Jameson, Diva and French Socialism, in Signatures of the I'isible at 55-62 (cited in note 20). 
performance-a relationship which cannot be intended, induced or created, she implies, but can only be experienced by an audience in the moment of its construction.

And then, finally, the danger past, Jules and the Diva find themselves alone together in the darkened Opera house. She is on stage, rehearsing scales. Jules is in the sound equipment room, high above the mezzanine. She does not know he made the tape; it exists merely, as it were, in the anonymity of a murmur. What does it matter that he made it or that she is singing? And yet of course it does matter, terribly-indeed, in the moment, as he begins to play the tape and they embrace, it is everything between them that she know.

"It's yours," he says; "it is my gift to you."

"But I've never heard myself sing," she protests.

And he replies, "Listen."

In the post-literate millennium, as in Diva, I believe, technology finally will sweep away all resistance to meaning, and all constraints beyond the individual. And authorship in the form of creative play will flourish in that time, not in the anonymity of a murmur, but as if in moments between lovers exchanging gifts.

\section{Conclusion}

If intellectual property survives, it will be obliged to reckon with a reality foreign to its origins. No longer will it lend itself to the construction of authorship for the purpose of advancing and suppressing speech. Perhaps there will be room for encouragement of productivity and for appropriation of investment even so. But there will be no place for suppression; no balances to be struck against the interests of creativity; and no moral rights of authors to be served, save this one: that anyone who wishes will be free to play in the fields of the word. 
· 